\title{
Sosial Criticism of Minangkabau Cultural in The Persiden Novel by Wisran Hadi
}

\author{
Refvia Jerita $^{1}$, Nila Oktami ${ }^{2}$, Nurrizati ${ }^{3}$ \\ \{refviajerita@student.unp.ac.id ${ }^{1}$, nilaoktami57@gmail.com², nurizzati@fbs.unp.ac.id ${ }^{3}$ \} \\ 1,2,3 Universitas Negeri Padang, Jalan Prof. Dr. Hamka Air Tawar Padang West Sumatra 25131, \\ Indonesia
}

\begin{abstract}
Wisran Hadi in the novel Persiden revealed the social problems that occur in the Minangkabau community. The purpose of writing this article is to describe the type of problems or social criticism in the novel Persiden Wisran Hadi. These results indicate that the novel form of social criticism Persiden Hadi Wisra work covering issues of culture, customs, religion, law, and politics. These social problems are conveyed in a direct and indirect form. Clearly, this criticism is a critique of (1) the problem of government bureaucracy that is not functioning as it should; (2) a Mamak who does not understand the condition of a nephew and Sumando who likes to interfere in matters that exist within the wife; (3) the rapidly growing number of political parties; (4) community morals that deviate from religious norms, the function of surau, and changes in beliefs; and (5) traffic rules, demonstrations, and building placement guidelines do not comply with the law.
\end{abstract}

Keywords: social criticism, Minangkabau culture, Persiden novel.

\section{Introduction}

Novel Persiden work explores Hadi Wisran about the cultural issues of the Minangkabau community in which the work was born. Wisran Hadi presents a side of the cultural environment that is experiencing complexity due to globalization. Various socio-cultural change events that become problems, such as issues of customs, culture, and sexual violations are presented so clearly and contrary to the idealized environment. If examined further, globalization has an impact on government policies that pay less attention to the culture of the Minangkabau people [1].

Based on previous research reviews, research that is relevant to this research is Sugiarti's research about the representation of Minang's identity and ethnicity in the novel Persiden by [2]. [3] about a shift in the value of the Minangkabau culture in the novel From Surau to Church Helmidjas Hendrawork and novel Persiden work [3]; and [2,4] about the representation of cultural ecology in the novel Persiden and Seventh Generation by [4]. Previous research generally explained the representation of Minangkabau culture in the novel by [2]. The results of [3] and [4] explain the representation of the Bagonjong house as ancestral inheritance, family tree, community lifestyle, the principle of living in dealing with shame, and the position of the husband only as a descendant maker [2,4]. Meanwhile, the results of [3] research explained that in the Novel Persiden by [2] there was a shift in social 
life that was no longer in line with Minangkabau cultural values caused by economic and modernization factors [3].

When examined more deeply, the causes of social life shifts that can be represented in previous studies are due to social inequalities. Efforts are made to provide an assessment of the problems or social gaps that occur in the community is with social criticism. Therefore, the writer will examine the socio-cultural criticism of the Minangkabau in the novel Persiden by Wisran Hadi. Social criticism will be examined in the form and factors that cause social criticism.

In a literary work, social criticism is the author's means to express his dissatisfaction with the joints of community life. Literature reflects social problems that exist in society, and if the author has a high level of sensitivity, his literary work will certainly cause social criticism (perhaps hidden) in that society [5]. Literature that contains messages of criticism will usually be born in the middle of society if things go wrong in social life in society [6]. The Minister of State Secretary, Moerdiono [7] said:

Some of the poems inevitably contain social criticism of various irregularities that occur in development. Personally, I think that we need to accept the social criticism of the poets naturally and gracefully. We can and need to understand the social criticism of poets as input to refresh our social, national, and state life

Such social criticism is not new. For hundreds of years, the puppeteers have been doing it past the inserts of the goro-goro in the standard wayang story that is shown. More than that, the treasures of world literature are so rich with literary works that contain social criticism.

Starting from some of the opinions above, it can be concluded that social criticism in literary works is one form of communication in the form of innuendo, responses, objections to things that are deviated, violate the rules, laws, and values in a literary work. Without criticism, literature can indeed progress but with criticism of the contribution of literature to cultural life and humanities knowledge can be more complete. Literature without criticism is like a campfire without wind, does not burn and does not provide optimal warmth.

Social criticism studies include politics, economics, law, religion, customs, culture, and defense and security. The form of the delivery of social criticism in literary works can be both direct and indirect [6]. First, the form of direct delivery is by describing a description or explanation. Second, in the indirect delivery, this message is only conveyed implicitly in the story, combined, coherence with other elements of the story. Based on previous studies and exposure to the material, this article discusses the social criticism in the novelMinangkabau culture Persiden Wisran works Hadi. Social criticism will be examined in the form and factors that cause social criticism.

\section{Method}

The research method used in this research is a descriptive. The research method is intended to describe the situation of a subject which contains social criticism in the novel Persiden Wisran works Hadi. The type of descriptive method used is descriptive analysis, which is the method used in dealing with one variable and is more exploratory. The approach used in the method is qualitative. This research data is a quote or sentence exposure to the narrator, narrative characters, or action figures that can be formulated as a social novel permaslahan Persiden Wisran works Hadi. The data source in this research is the novel of Persiden by [2]. 
The main instrument of this study is the researchers themselves, starting from direct read, identify, clarify, and interpret a sentence that can be abstracted in social criticism on novel Persiden Hadi Wisran work. The research tools used are in the form of recording and analyzing data. The data validation technique used in this study is a detailed description technique. The detailed description technique requires the researcher to report the results of his research so that the description is done as carefully and as carefully as possible which illustrates the research context and refers to the focus of the study [8]. The data validation technique in this study was carried out by interpreting the data with direct evidence taken from quotations containing social criticism of the novel Persiden by Wisran Hadi. The final stage of this research is to conclude the results of the study and make a report.

\section{Result and discussion}

After analyzing the novel Persiden by Wisran Hadi, a social point was found that included issues of culture, customs, religion, law, and politics. Social criticism is conveyed in the form of direct and indirect. Wisran Hadi takes the reader to a mall called President, which the local people have pronounced "President", a change which the narrator said was "additional mockery caused by public anger at the management and appearance President's that was not environmentally friendly". This study analyzes and describes the social criticism in the novel Persiden Wisran works Hadi. Based on the research, found a wide range of social criticism contained in the novel Persiden Wisran works Hadi, described below.

These results indicate that the novel form of social criticism Persiden Hadi Wisra work covering issues of culture, customs, religion, law, and politics. These social problems are conveyed in a direct and indirect form. Clearly, this criticism is a critique of (1) the problem of government bureaucracy that is not functioning as it should; (2) a Mamak who does not understand the condition of a nephew and Sumando who likes to interfere in matters that exist within the wife; (3) the rapidly growing number of political parties; (4) community morals that deviate from religious norms, the function of surau, and changes in beliefs; and (5) traffic rules, demonstrations, and building placement rules do not comply with the law.

\subsection{Critics of cultural issues}

Minangkabau culture is very clearly depicted in this novel. However, protests against culture astonish the reader especially in terms of the construction of government buildings in the Minangkabau area whose roof always resembles the oval shape of a Gadang House. An office whose roof mimics the roof of a traditional house is called Bagonjong House. In the Minangkabau tradition that is by tambo, Bagonjong House is a Gadang House built by a people in which there are prince, niniak mamak, and clever. Bagonjong's house in the Minangkabau function is used as a place to stay and a place to gather in discussing traditional issues. In the development of culture in Minangkabau, office roofs may imitate the roof of a Gadang House, but not in the name of a name because the two things have different functions and meanings. Thus, the designation of the House of Bagonjong for a government office is not feasible because it has nothing to do with the customary family tree.

Four hundred and fourteen meters less than the Persiden down the Katib road toward the center of the city, to the left of the road, stood a large, tall office. The roof is made to tilt as the roof of a traditional house, even though the building 
has no connection with customs ... A large office whose roof is attached to the roof of a traditional house is also called Bagonjong House (Persiden, p. 14).

The government has felt proud of the architecture of the roof of the building resembled the oval of a Gadang House because it indicated that the government system had glorified a high and strong spirit of the culture. In fact, the buildings that were given the gonjong did not reflect the Minangkabau traditional values, but the bureaucrats' offices were based on customs which were far different from the procedures and customs which they said they maintained through the traditional form of the traditional house.

\subsection{Criticism of adat issues}

In the novel Persiden by Wisran Hadi there are adat issues especially the role of Sumando and the role of Mamak in Minangkabau. Sumando is a Minangkabau language for men who joins a family of women who is tied with a marriage string. Sumando was treated as an honored guest. Sumando, respected, treated by his wife, is manatiang minyak panuah which means his presence is highly respected and respected. However, on the other hand some are treated bak abu diateh tungkua which means they are not valued. The role of Sumando is only to participate in making decisions that affect the affairs of the property of their children, and supervision of the finances of his wife and children, basically the father's power is very limited in the wife's house [9]. Sumando's position in the wife's family is very fragile. The traditional proverb of Minangkabau says Sumando, "bak abu di ateh tungku" (like ashes on a stove). Ash is the result of the combustion process of the furnace which is very easy to clean. Just a little wind, the ash will go from the furnace. This expression means that the position of a Sumando in his wife's family is easily displaced if he is caused by a problem.

The role of the Sumando told in this novel is the role of the Sumando who likes to interfere in the affairs of the wives and Sumandos who are not good at society. In such a case it is called "sumando kacang miang". Sumando kacang miang is a bad behavior, making chaos, chaos and often slandering or fighting sheep. One of the worst behaviors in social interaction. This behavior is very much avoided and kept away from every human being. Pa Lendo always interfered in the problems that occurred in the Bagonjong House, as evidenced in the following quote.

If the turmoil in the family happens again, it can also spread to the existence of $\mathrm{Ci}$ Inan's husband. Ci Inan's husband, Pa Lendo likes to be crazy and always threatens to slaughter people. Anyone who is considered to disturb the peace of his wife and children will be slaughtered. If the threat had been carried out, perhaps two hundred and fifteen Paratingga people had lost their heads (Persiden, p. 45).

The role of Mamak in Minangkabau is in stark contrast to the role of Sumando. Mamak in Minangkabau is the brother of a female parent. Mamak must play a deeper role in understanding nephews. A Mamak must understand about his nephew, he must know what problems occur to his nephew. Adat teaches that brothers must take responsibility for the safety and survival of their sisters and children because of the inheritance and inheritance of inheritance. If people do not have female offspring, it means that the people are extinct. Results of research by Hudiya, R, et al. stated the role of Mamak in the Minang migrant community namely guiding nephews in terms of inheritance of roles, taking care of marriages, 
resolving disputes, managing the household economy of the nephews, while the role of Mamak in heirloom assets cannot be applied overseas because the property of the nephew here is private property originating from father's quest for wealth did not originate from the legacy of our ancestors [10].

The rights and powers of deliberation and consensus are in the hands of nephews and Nagari children who are carried out by princes, clerics and clever called "tali tigo sapilin, tungku tigo sajarangan " expressed in the traditional saying: "Kamanakan barajo ka Mamak, Mamak barajo ka mufakat, mufakat mufakat barajo ka bana, nan bana badiri sandirinyo [11]. AA Navis explained in his book that the Mamak family ties and nephews are the relationship between a man and his mother's brother's son or the relationship of a boy with his sister's child [12].

In this novel, the Mamak is told who does not understand the condition of his nephew. The nephew was impregnated by someone else, married to the person who impregnated her, and her child was born but mamak didn't know that. This is evidenced in the following quote.

You Mamaknya! Four men! All great! Journalists, lecturers, migrated to the neighboring country, the treasurer of the provincial Public Works, the temperature of the children of the President also, descendants of clerics, civilized people! How could you not know about his niece being cheated by someone else! what kind of man are you What kind of moms are you! (Persiden, p. 62).

Tsuyoki Kato said that at present the father and mother are more responsible and responsible for ensuring the welfare of their children even though occasionally they are also assisted by Mamak [14]. Lkaam in his book said that in the past, Mamak was fully responsible for the interests of his nephews. However, there is now a shift in values in the relationship between Mamak and nephews. The relationship between Mamak and nephew began to stretch [13, 14]. In addition to being responsible for the safety and survival of his sister and children, Mamak also plays a role in the inheritance of heirlooms. Mamak told in this novel is a mamak who is not responsible for the inheritance, namely Rumah Bogonjong which is the only inheritance of the people. They did not care about the condition of the Bagonjong House which had been aged.

"You leave the Bagonjong House that has been leaked! Soon it will collapse! Why don't you watch this collapse! "Pa Mikie shouted standing on the steps of the mossy Bagonjong House. (Persiden, p. 375).

\subsection{Criticism of religious issues The problems}

Relates to religion in this novel relate to the moral problems of the people of the President who deviate from the rules of religion, the surau (place of worship) that changes their function, and changes in beliefs. Regarding the morality of the people of the President, who deviated from religious values in general in the association of teenagers who were free and uncontrolled.

Day and night the President visited. Often seen young women who are still attending the school come to the disco with tacky and stimulating makeup. That said, they want to entertain themselves, music while dancing happily. People say 
they secretly attach or sell the body there. God knows you, man. In the dark who knows. (Persiden, p. 4).

How powerful the President was, man. In taxis lined up along the road in the opposite lane, couples moaning in adultery, while in other lanes people click and hold their breath watching the acrobatics of luxury cars, and gulp when losing in gambling (Persiden, p .5).

The problem of the surau (place of worship) changing its function is very alarming to readers and the public. Reality at this time many old mosques (place of worship) are not used anymore and its function has changed. Surauang is a term for an old surau in this novel with many deviations occurs. Surau has been converted into a place for teenagers to play, such as playing English drama, karate training, debating economic and political issues, and other activities whose actions are no longer by Islamic teachings. Previously the name of the surau was Teleang Surau because it was increasingly tilted as a result of being located on the edge of the river, then out of anger, the old people called the name of the surau now Surauang. The effect of surau waang or Suraumu. Unfortunately, young people like that title.

Once there was a dispute between old people and young children in the case of Surauang. Old people want to finish off all activities by dismantling the mosque. They consider that surau has become an arena for young people whose actions are no longer by Islamic teachings. There have been many deviations. They play English drama not the plays of the prophets, karate training is not an exercise in tradition, debating economics and politics, not religious matters. They sing not the songs of the Qasidah (Persiden, p. 92).

\subsection{Criticism of legal issues}

In this novel binding laws or rules imposed by the government cannot yet be implemented properly, such as traffic rules, demonstrations, and building placement guidelines. The rules then intas always denied by the user is proven by the following quote.

They play cat and mouse with the traffic police. If there are police standing there, they obey the traffic rules, but if the police leave they return to violation (Persiden, p. 6).

"Traffic rules are only for the police", said the topic-driver calmly while glancing at the stall where the police were resting (Persiden, p. 6).

\subsection{Criticism of political problems}

The narration of the Persiden novel was not free from the political problems that were rife at the time. The political problems in this novel are the problems of building and dismantling monuments for political needs, demonstrations, the rapidly growing number of parties, and the misuse of buildings related to politics. For the problem of monuments, the city of Padang that is told in this novel deserves to be a monument city nickname because in almost every intersection, bus terminal, and reclamation site a monument was established. However, this 
development only consumes state money. None of these monuments last long, according to the following quote.

Many such monuments were demolished by officials in power, then on the ruins, new monuments were built according to their taste. Like the monument at the President, for example, was made based on the taste of the wife of an official in power. When asked why all of that was built, then the answer of everyone who is asked will be the same: the project. That is, building a monument like that is one way to spend state money without the need to account for the amount, quality, or value of its art (Persiden, p. 8).

Increasingly, the party is increasing in number. Social criticism in the problem of the increasing number of parties is likened to the color of the fence of one of the citizens of the house as follows.

Because the party now has many in number and also many other colors used to represent their party. Jinaha intends to add color to the fence as much as the number of parties. His house will be fenced in colors, as the colors are the symbol of the party. However, now the intention cannot be implemented because a lot of paint is missing on the market. (Persiden, p. 109).

In the case of misuse of buildings related to politics, the Balai Pemuda office is bigger than the mosque which stands across the street in front of it, is more beautiful than a schoolhouse or lurah office, and is cleaner than a hospital. From the size, completeness, and beauty it can be estimated how great harmony, prosperity, and youth groups are there. However, the building turned out to be a place where former mayors, former regents, retired high-ranking officers, old businessmen, gathered and reminisced.

\section{Conclusion}

Social criticism is one form of communication in the form of innuendo, responses, rebuttal to deviant things, violate the rules, laws, and values. Based on the results of an analysis of the novel Persiden by Wisran Hadi, social criticism is found covering cultural, cultural, religious, legal and political issues. These social problems are conveyed in a direct and indirect form. First, the construction of government buildings which always resembles the gadang gonjong house, but has a function that deviates from the Minangkabau culture. The construction of a government building whose roof always resembles a gadang gonjong shape, but the building is the office of bureaucrats with far different customs. Meanwhile also explained the issue of the relationship of making monuments with Minangkabau culture. Second, in the novel Persiden Wisran Hadi works there are problems, especially indigenous Sumando role and the role of Mamak Minagkabau. Mamak who does not understand the condition of the nephew and Sumando who likes to interfere in the affairs of the wives. Third, the political problems in this novel are problems of building and dismantling monuments for political needs, demonstrations, the rapidly growing number of parties, and the misuse of buildings related to politics. Fourth, the problems relating to religion in this novel are related to the moral problems of the people of the President who deviate from the rules of religion, the surau (place of worship) that changes their function, and changes in beliefs. Fifth, in this novel binding laws or rules imposed by the government, cannot yet be implemented properly, such 
as traffic rules, demonstrations, and building placement guidelines. There factors are causing social criticism, namely economic factors, psychological factors, and cultural factors.

\section{Acknowledgments}

This article was realized thanks to helping from various parties. The author would like to thank all parties who are willing to contribute data to this article. The author also thanked the Lecturer who has given criticism and suggestions for the perfection of this paper.

\section{References}

[1] Hadi, W.: Persiden. (Yogyakarta: PT Bentang Pustaka) (2013)

[2] Sugiarti.: Representasi identitas dan etnis Minang dalam novel Persiden karya Wisran Hadi. Vol. 2, pp 26-38. Universitas Muhammadiyah Malang. (2013)

[3] Anggraini, N.: Pergeseran nilai budaya Minangkabau dalam novel Dari Surau ke Gereja karya Helmidjas Hendra dan novel Persiden karya Wisran Hadi. Vol. 1, pp 63-70. DINAMIKA UMT. (2015)

[4] Sugiarti, Putra C. R. W.: Representasi ekologi budaya dalam novel Persiden dan Generasi Ketujuh karya Wisran Hadi. Vol. 18, pp 17-35. LITERA. (2019)

[5] Damono, S. D.: "Kritik sosial dalam sastra Indonesia: lebah tanpa sengat" dalam kesusastraan Indonesia modern, beberapa catatan. (Jakarta: PT Gramedia) (1983)

[6] Nurgiyantoro, B.: Teori pengkajian fiksi. (Yogyakarta: Gadjah Mada University Press) (2005)

[7] Rendra, W. S.: Penyair dan kritik sosial. (Yogyakarta: KEPEL Press) (2001)

[8] Moleong, L. J.: Metodologi penelitian kualitatif . (Bandung: Remaja Rosdakarya) (2010)

[9] Benda, B.: Properti dan kesinambungan sosial. (Jakarta: PT Gramedia) (2000)

[10] Hudiya R, Iskandar S, Ali I.: Peran mamak pada masyarakat Minang perantau di Desa Merak Batin. (FKIP UNILA) (2017)

[11] Lkaam.: Pengetahuan adat Minangkabau. (Padang: Ratu Grafika Padang) (2000)

[12] Navis, A. A.: Alam takambang jadi guru. (Jakarta: Pustaka Grafiti) (1984)

[13] Kato, Tsuyoshi.: Adat Minangkabau dan merantau dalam pespektif sejarah. (Jakarta: PT Balai Pustaka) (2005)

[14] Kato, T.: Rantau pariaman: dunia saudagar pesisir Minangkabau abad XIX, dalam Akira Nagazumi, Indonesia kajian sarjana Jepang perubahan sosial ekonomi abad XIX dan XX dan berbagai aspek nasionalisme Indonesia. Jakarta. Yayasan Obor Indonesia, pp 77-115. (1986) 